\title{
Genetic and Non-Genetic Factors Affecting Reproductive Traits of Pakhribas Pig in Nepal
}

\author{
Shreeram P. Neopane \\ Animal Breeding Division, Khumaltar, PO Box 1950, Kathmandu <spneopane04@yahoo.com>
}

\begin{abstract}
Pakhribas pig is a black colour pig and is highly preferred by the people in the Eastern hills of Nepal. This breed was developed in Nepal by three-way crossing of exotic breeds (Saddle back, Fayuen and Tamworth) at Agricultural Research Station (ARS), Pakhribas, the then Pakhribas Agricultural Centre (PAC). The data of 348 pigs, born over a period of fifteen years (1990 to 2004) were used to study the effect of non-genetic factors on reproductive traits and estimate their genetic parameters. The findings revealed that the overall gestation length and farrowing intervals were $113.7 \pm 0.12$ days and $182.5 \pm 2.2$ days, respectively. Season of birth and parity of dams were not important sources of variation for reproductive traits, where as year affected these traits significantly. Heritability estimates of gestation length was low $(0.02 \pm 0.094)$, but heritability for farrowing interval was moderate $(0.14 \pm 0.147)$ suggesting selection based on farrowing interval would bring the improvement in the trait.
\end{abstract}

Key words: Genetic and non-genetic parameters, hills of Nepal, Pakhribas pig, reproductive traits

\section{INTRODUCTION}

Pakhribas pig is a result of three-way crossing of exotic breeds (Saddle back, Fayuen and Tamworth) developed at Agricultural Research Station (ARS), Pakhribas, the then Pakhribas Agricultural Centre (PAC) (Oli 1986, Gatenby et al 1990, Aryal et al 1992). The breed is very popular in the eastern hills of Nepal because of its black colour and a good litter size at birth and weaning (Gatenby et al 1990). For religious purposes, black colour is preferred over other colours in the eastern hills. It is medium in size and can be maintained by the farmers in the hills.

The performance records indicate that they are good in productive characters including the reproductive parameters. A study carried out at On-farm situation aiming to compare the productivity of Pakhribas pigs with the local and its crossbred with Pakhribas pigs showed that the Pakhribas pigs produced $90 \%$ more meat than the local and $60 \%$ than its crossbreeds at the farmers' feeding and husbandry system (Oli 1986). This indicated that Pakhribas pigs are more productive and well suited to local environments.

Information on genetic and non-genetic parameters of litter traits for Pakhribas pigs is available (Neopane 2005). However, information on the non-genetic and genetic factors affecting reproductive traits is not available for Pakhribas pigs. The study was undertaken to estimate the nongenetic factors affecting reproductive traits and estimate their genetic parameters. In order to accomplish the study, a retrospective study was done and for this data obtained over fifteen years were analysed. 


\section{MATERIALS AND METHODS}

The study was conducted at Pakhribas Agricultural Centre (PAC), Dhankuta district, in the Eastern mid hills of Nepal. The area was located at an altitude of $1740 \mathrm{~m}$ above sea level. The geographical location is $27^{\circ} 17^{\prime} \mathrm{N}$ and $87^{\circ} 17^{\prime} \mathrm{E}$.

Records of pigs born from sixteen sows and four boars were used for the study. Pigs with piglets were kept at separate farrowing pen. Piglets were provided heat by electric bulbs. In farrowing pen rice straw was kept in order to make bed for the mother and also to maintain the temperature. Piglets were weaned at 6 weeks of age and at this age they were distributed to the farmers.

Data recorded over fifteen years (1990 to 2004) for reproductive traits of Pakhribas pigs at the centre were analysed to estimate genetic and non-genetic factors affecting the traits. For this least-squares analysis techniques based on unequal subclass (Harvey 1990) were performed using the following model;

$Y_{i j k}=u+a_{i}+b_{j}+c_{k}+e_{i j k l}$

Where, $\mu$ is overall mean

$a_{i}$ is the effect of $i_{\text {th }}$ parity of dam $(i=1,2, \ldots . .14)$

$b_{j}$ is the effect of $j_{t h}$ season of birth $(j=1,2,3)$

$c_{k}$ is the effect of $k_{t h}$ year of birth $(k=1,2, \ldots . .15)$

$\mathrm{e}_{\mathrm{ijk} \mathrm{l}}$ is a random element assumed to be normally and independently distributed

An overall analysis, ignoring sires and dams, was used first to examine environmental effects. Then sires and dams were included in the model as random effects to estimate the genetic components of variance and to eliminate non-significant fixed effects (Harvey 1990).

\section{RESULTS AND DISCUSSION}

\section{Non-genetic factors}

Least-square means of reproductive traits are presented in Table 1. The least square mean of farrowing interval (FI) in the herd was $182.5 \pm 2.2$ days. This value corresponds to earlier reports for Pakhribas pigs (Aryal et al 1992, Shrestha 2000). The figure was slightly lower than the average records of 191 days by Dhaubdel and Pokharel (1997) using the three genotypes (Landrace, Yorkshire and their crosses) in Khumaltar, Kathmandu, Nepal. A higher value of farrowing interval was also reported for Landrace (196 days) and Yorkshire (206 days) in Kathmandu, Nepal (SARP 1992). These indicated that Pakhribas pigs are better than exotic breeds in terms of farrowing intervals.

The least square mean of gestation length (GL) in the herd was $113.7 \pm 0.12$ days. The value obtained was close to the records reported by Shrestha (2000) for Pakhribas pigs. This value also corresponds to the value reported by Fahmi and Bernard (1972) for European breeds of pigs. The value is well in range within values reported in the literature.

Parity of dam and season of birth were not important source of variation for reproductive traits (Farrowing interval and Gestation length). This suggested that the Pakhribas pigs can be reared up to $14^{\text {th }}$ parity without any decline productivity level. Year was however, significant source of variation for farrowing interval $(\mathrm{P}<0.05)$ and gestation length $(\mathrm{P}<0.001)$. The probable reason for significant effect of year on farrowing interval was better environment (mild climate, less parasitic burden, less diseases, etc) in some years than others. Year itself is not a good environmental or nongenetic factors for any production traits (farrowing interval). However, its effect has to be corrected before heritability estimation of the trait is made. 
Table 1. Least-squares means of reproductive traits (days) of Pakhribas pigs for different non-genetic factors

\begin{tabular}{|c|c|c|c|c|c|c|}
\hline \multirow[t]{2}{*}{ Factors } & \multicolumn{3}{|c|}{ Farrowing interval } & \multicolumn{3}{|c|}{ Gestation length } \\
\hline & $\mathrm{N}$ & Mean & $\mathrm{SE}$ & $\mathrm{N}$ & Mean & $\mathrm{SE}$ \\
\hline Overall & 307 & 182.5 & 2.2 & 348 & 113.7 & 0.12 \\
\hline \multicolumn{7}{|l|}{ Parity of dams } \\
\hline 1 & - & - & - & 40 & 113.3 & 0.30 \\
\hline 2 & 42 & 179.9 & 5.1 & 42 & 113.9 & 0.32 \\
\hline 3 & 32 & 179.1 & 5.6 & 32 & 112.8 & 0.34 \\
\hline 4 & 30 & 177.2 & 5.7 & 30 & 113.8 & 0.34 \\
\hline 5 & 28 & 185.6 & 5.9 & 28 & 113.9 & 0.36 \\
\hline 6 & 25 & 171.1 & 6.3 & 25 & 113.3 & 0.39 \\
\hline 7 & 23 & 177.4 & 6.2 & 23 & 113.5 & 0.38 \\
\hline 8 & 22 & 184.0 & 6.3 & 22 & 113.9 & 0.39 \\
\hline 9 & 20 & 181.9 & 6.8 & 20 & 114.3 & 0.39 \\
\hline 10 & 19 & 179.3 & 6.8 & 20 & 113.9 & 0.42 \\
\hline 11 & 18 & 183.5 & 7.3 & 18 & 113.8 & 0.45 \\
\hline 12 & 17 & 182.6 & 7.4 & 17 & 113.8 & 0.46 \\
\hline 13 & 16 & 203.4 & 8.1 & 16 & 114.4 & 0.50 \\
\hline 14 & 15 & 187.8 & 7.9 & 15 & 113.8 & 0.49 \\
\hline F-test & \multicolumn{3}{|c|}{$\mathrm{ns}$} & \multicolumn{3}{|c|}{$\mathrm{ns}$} \\
\hline \multicolumn{7}{|l|}{ Season of birth } \\
\hline $\begin{array}{l}\text { Early dry (Dec- } \\
\text { Feb) }\end{array}$ & 65 & 185.9 & 4.4 & 75 & 113.5 & 0.25 \\
\hline $\begin{array}{l}\text { Late dry (Mar- } \\
\text { May) }\end{array}$ & 91 & 177.4 & 3.4 & 105 & 113.6 & 0.19 \\
\hline Wet (Jun-Nov) & 151 & 184.2 & 2.6 & 168 & 114.1 & 0.15 \\
\hline F-test & \multicolumn{3}{|c|}{$\mathrm{ns}$} & \multicolumn{3}{|c|}{ ns } \\
\hline \multicolumn{7}{|l|}{ Year of birth } \\
\hline 1990 & 12 & 174.5 & 12.9 & 15 & 115.1 & 0.50 \\
\hline 1991 & 13 & 182.9 & 8.1 & 14 & 113.6 & 0.49 \\
\hline 1992 & 13 & 190.1 & 8.0 & 19 & 115.2 & 0.42 \\
\hline 1993 & 15 & 198.5 & 7.6 & 15 & 113.9 & 0.47 \\
\hline 1994 & 16 & 187.9 & 7.3 & 20 & 113.3 & 0.41 \\
\hline 1995 & 22 & 186.3 & 6.4 & 25 & 113.1 & 0.38 \\
\hline 1996 & 26 & 183.6 & 5.8 & 29 & 113.3 & 0.35 \\
\hline 1997 & 28 & 193.5 & 5.6 & 30 & 113.9 & 0.34 \\
\hline 1998 & 32 & 174.8 & 5.1 & 32 & 112.3 & 0.32 \\
\hline 1999 & 30 & 166.9 & 5.4 & 30 & 113.1 & 0.34 \\
\hline 2000 & 21 & 169.5 & 6.3 & 27 & 112.8 & 0.35 \\
\hline 2001 & 22 & 186.6 & 6.2 & 24 & 113.0 & 0.37 \\
\hline 2002 & 21 & 175.8 & 6.3 & 25 & 114.7 & 0.36 \\
\hline 2003 & 19 & 184.6 & 8.2 & 23 & 114.8 & 0.46 \\
\hline 2004 & 17 & 182.5 & 7.8 & 20 & 114.6 & 0.44 \\
\hline F-test & \multicolumn{3}{|c|}{$*$} & \multicolumn{3}{|c|}{$* * *$} \\
\hline
\end{tabular}

$N$, Number of records. SE, Standard errors. 


\section{Genetic factors}

Heritability estimates of reproductive traits are presented in table 2. Heritability estimates of gestation length was low $(0.02 \pm 0.094)$ but estimates of heritability for farrowing interval was moderate $(0.14 \pm 0.147)$ suggesting selection based on farrowing interval would bring the improvement. Crump et al (1997) reported moderate estimates of heritability for gestation length. Estimates of heritability for farrowing interval from the study are close to several research reports (Johansson 1981, Rydhmer et al 1995, Tholen et al 1996, Crump et al 1997). However, some other authors have reported lower estimates of heritability for farrowing interval ranging from 0.06 to 0.09 (Johansson and Kennedy 1985, Adamec and Johnson 1997, Oh et al 2005). Haley et al (1988) reviewed the estimates for farrowing intervals within a range of 0.04 to 0.22 .

Table 2. Heritability estimates of reproductive traits of Pakhribas pigs

\begin{tabular}{lrr}
\hline Trait & Heritability & Standard error \\
\hline Farrowing interval & 0.14 & 0.147 \\
Gestation length & 0.02 & 0.094 \\
\hline
\end{tabular}

Low to moderate estimates of heritability indicated that some genetic variance is available for these traits and hence selection based on the trait (farrowing interval) may bring genetic improvement and consequently improve productivity by reducing farrowing interval.

\section{CONCLUSION}

Non-significant effect of parity on farrowing interval (1-14 parity) suggested that the pigs may be reared up to 14 parity without declined productivity level in terms of farrowing intervals. Moderate estimates of heritability for farrowing interval indicated that the dams if selected based on the shorter farrowing interval may improve the traits.

\section{REFERENCES}

Adamec V and RK Johnson. 1997. Genetic analysis of rebreeding intervals, litter traits and production traits in sows of the National Czech nucleus. Livest. Pro. Sci. 48:13-22.

Aryal IK, NP Shrestha, BB Kshatri, PP Rai and MP Shrestha. 1992. Some characteristics of Pakhribas pigs. Veterinary Review 7(10):21-23. Pakhribas Agricultural Centre, Dhankuta, Nepal.

Crump RE, CS Haley, R Thompson and J Mercer. 1997. Individual animal model estimates of genetic parameters for reproduction traits of landrace pig performance tested in a commercial nucleus herd. Animal Sciences 65:285-290.

Dhaubdel TS and PK Pokharel. 1997. Piglet mortality: A big economic penalty to the pig farmers. In: Proceedings of the II nd National Workshop on Livestock and Fisheries Research, 24-25 September 1997. National Animal Science Research Institute (NASRI), Nepal Agricultural Research Council (NARC), Khumaltar, Lalitpur, Nepal. Pp. 175-178.

Fahmy MH and CS Bernard. 1972. Reproductive performance of gilts from lives selected from feed utilisation and carcass score. Canadian Journal of Animal Sciences 52:267271.

Gatenby RM, PB Chemjong and SK Chimariya. 1990. Reproduction of pigs in the Koshi Hills. PAC Technical Paper No 125. Pakhribas Agricultural Centre, Dhankuta, Nepal.

Haley CS, E Avalos and C Smith. 1988. Selection for litter size in the pigs. Anim. Breed. Abst. 56:317-332.

Harvey WR. 1990. User guide for LSMLMW PC-2 version. Ohio State University Press Columbus, USA. 
Johansson K and BW Kennedy. 1985. Estimation of genetic parameter for reproductive traits in pigs. Acta Agric Scand. 34:421-431.

Johansson K. 1981. Some notes concerning the genetic possibilities of improving sow fertility. Livest. Prod. Sci. 8:431-447.

Neopane S P. 2005. Genetic and non-genetic factors affecting litter traits in Pakhribas black pigs. Nepalese Veterinary Journal 28:51-57. Nepal Veterinary Association, Tripureshwor, Kathmandu, Nepal.

Oh SH, DH Lee and MT See. 2005. Estimates of genetic parameters for reproductive traits between first and later parities. Animal Science Departmental Report 2004-2005. North Caroline State University.

Oli KP. 1986. Comparative study of carcass yield of different breeds of pigs in the eastern hills of Nepal. PAC Technical paper No 99. Pakhribas Agricultural Centre, Dhankuta, Nepal.

Rydhmer L, N Lundeheim and K Johansson. 1995. Genetic parameters for reproduction traits in sows and relation to performance-test measurements. J. Anim. Breed. Genet. 112:33-42.

SARP. 1992. Annual report. Swine and Avian Research Programme, Nepal Agricultural Research Council, Khumaltar, Lalitpur, Kathmandu, PO Box 1950, Nepal.

Shrestha NP. 2000. Characterization of a pig developed at Pakhribas. In: Proceedings of the Fourth Global Conference on Conservation of Domestic Animal Genetic Resources. Nepal Agricultural Research Council, Khumaltar, Lalitpur, Nepal. Pp. 194-196.

Tholen E, KL Bunter, S Hermesch and HU Graser. 1996. The genetic foundation of fitness and reproduction traits in Australian pig populations. 2. Relationships between weaning to conception interval, farrowing interval, stayability, and other common reproduction and production traits. Australian Journal of Agricultural Research 47(8):1275-1290. 